\title{
Sino-American relations under Trump
}

\author{
George N. Tzogopoulos*
}

The future evolution of relations between the US and China will be critical for world developments. The former - an established political and economic superpower - and the latter - an unquestionably economic colossus and rising political power - are attempting to find a modus vivendi which will define international relations. Optimistic scholars suggest that existing and possibly new differences will either be solved peacefully or at least not lead to any conflict in the interest of world stability. However pessimistic analysts express the view that ongoing rivalry and contradicting interests will ultimately lead to armed conflict.

In 2010, former US President Barack Obama decided to respond to what China describes as its 'peaceful development' with the so-called 'pivot to Asia'. American foreign policy started to turn gradually towards Asia with the purpose of encircling Beijing politically, military and economically. At the political and military level Washington attempted to strengthen ties with traditional allies such as South Korea and Japan. And to gain economic advantage, it invested in the establishment of the TransPacific Partnership (TPP). China reacted by developing its 'Belt and Road' (OBOR) strategy, as well as seeking close relationships with Asian countries such as Bangladesh, Cambodia, Nepal and Pakistan.

The US presidential election of 8 November 2016 decided whether continuity or discontinuity would mark Sino-American relations. There was a fundamental difference between the two candidates. On the one hand, Trump represented what could be called an 'unknown factor' in international relations. And on the other hand, Hillary Clinton, an establishment politician, guaranteeing a rather similar approach to that of Obama vis-àvis China. Beijing greeted Trump's victory with caution. As we will see, his presidency can create some opportunities for it but might also cause serious misunderstandings and problems. Even before his inauguration, for instance, Trump alarmed Beijing by having a telephone conversation with Taiwan leader Tsai Ing-wen. ${ }^{1}$ Leading Chinese newspaper Global Times wrote subsequently that 'it is hoped that Trump will gradually understand the reality and shape his China policy based on it'. ${ }^{2}$ 
A trade war?

Donald Trump won the US presidential election with a rather revolutionary rhetorical agenda, with the reconsideration of trade policies seemingly high on the agenda. Trump labelled China a 'currency manipulator'. In promising to 'Make America Great Again', he also said he would bring back manufacturing jobs from China to the US and force American businessmen to reconsider their economic plans. Additionally, he would maybe seek to cut his country's trade deficit with China through new measures, perhaps including taxes on imports of cheap Chinese products and instituting more trade lawsuits against China, both in the US and through the World Trade Organization (WTO).

The new Commerce Secretary Wilbur Ross and the head of the newlyestablished White House National Trade Council, Peter Navarro, are widely considered as indications of Trump's planned hawkish approach. Ross and Navarro were Trump advisers during the election campaign and the inspiring figures behind his anti-globalization public remarks. In July 2016, they co-authored a $C N B C$ article identifying alleged flaws in existing trade agreements and portraying Trump as the man to fix things. They have criticized China's admission to the WTO in 2001, portraying it's aftermath as 'American companies go bankrupt, China takes over the market, and the court ruling becomes moot'. 3

As a successful and experienced investor, Ross is believed to have made money after George W. Bush introduced tariffs on Chinese steel imports in 2002. The New York Post has reported that a few weeks before, Ross had bought steel maker LTV Corp. which benefited greatly and was later sold at a very favorable price. ${ }^{4}$ Similarly, The New York Times refers to the new Commerce Secretary's business interests- such as establishing a consortium with Chinese companies - and rather ironically comments that 'for all the anti-China commentary, Mr. Ross has been a frequent visitor in the past two decades and has made inroads into its energy industry'. 5

Navarro is more a theorist than a practitioner. With a $\mathrm{PhD}$ in economics from Harvard University, he has been business professor at the University of California-Irvine for more than 20 years and was recently awarded the Distinguished Faculty Award for Teaching. He has a record of anti-China publications including the 2012 documentary film 'Death by China,' the principal message of which was to encourage viewers not to buy 'Made in China' products. Three years later, Navarro also touched upon geopolitics 
in a new book on 'China's militarism', analysing the scenario of a conflict between the two countries. ${ }^{6}$

The appointment of Ross, and even more so Navarro, has increased fears about a trade war between the US and China. The scenario cannot be excluded, as Trump has started his presidency showing a real will to align his policies with his pre-election agenda. However, many commentators and media have warned of the consequences. Fortune, for example, made a comprehensive analysis explaining "why America would lose a trade war with China. ${ }^{7}$ Moreover, the $C N N$ website found eight reasons why a trade war with China would be a 'bad idea' 8 and The New York Times predicted Trump 'couldn't win' this fight. ${ }^{9}$

China's reaction to aggressive US policies - such as heavy tariffs or sanctions, as touted by Ross and Navarro - will be immediate and equally strict. An example would be the Chinese preference of the European aircraft industry over American rivals. ${ }^{10}$

Nevertheless, the objective must surely be to prevent a trade war and not to assess the impact of consequences, as this situation will be a definite 'lose-lose' scenario. Trump's new trade team, which also includes billionaire Carl Icahn as an adviser on regulation issues, will soon need to decide whether, and to what extent, it will proceed with the implementation of the relevant pre-election programme. With reference to China, the risk goes beyond economics. Sino-American relations are and will continue to be critical to world geopolitical stability. Thus, every single barrier could perhaps alter or lead to a change of the existing balance of power.

\section{US withdrawal from TPP}

Trump is generally considered to be a president who will open a new chapter in US support for globalization as he supports protectionism and disagrees with the logic of free trade agreements. His decision to withdraw his country from the Trans-Pacific Partnership (TPP) is a significant indication of his will to proceed with his pre-election agenda on the matter. ${ }^{11}$ Although the TPP wasn't expected to pass a vote in Congress, Trump's executive order confirmed the withdrawal.

At first glance, the Obama-led US pivot to Asia is suffering a practical blow. The TPP aimed at boosting the former president's effort to encircle China at the economic and trade levels. Now that this policy cannot be implemented via TPP, a debate on the consequences, as well as what should 
be done next, is flourishing. The American establishment does not look favorably at Trump's decision to pull out of this trade deal. Coverage by mainstream media is indicative. The Washington Post expressed its disagreement and connected it with future benefits for China. An article saw the 45th US President 'giving China its first big win' and '[handing it] its clearest opening yet to tilt the geopolitical balance in Asia in its favor.' 12 In the same vain, Bloomberg diagnosed that Trump gave a 'gift' to China and 'damaged American prestige'. ${ }^{13} C N N$ also asserts that the 'door [is] open for Beijing to push its own brand of trade.' 14

How has China reacted to all of this? For a period of approximately one year the country has paid careful attention to Trump's rhetoric while slowly developing its own policies. To start with, the Regional Comprehensive Economic Partnership (RCEP) outlines Beijing's goal to promote negotiations on trade in goods and services while improving access to investment markets in 16 Asian participating economies. ${ }^{15} \mathrm{~A}$ recent White Paper on China's Policies on Asia-Pacific Security Cooperation makes particular reference to RCEP. Parallel to this, the country places emphasis on boosting integration in the Asia-Pacific region. President Xi Jinping clarified this priority in a speech he gave at the APEC Summit in Lima a few days after the U.S. presidential election.

The question to be asked is whether Trump's executive order on TPP could accelerate the achievement of China's goals. This would appear to be the case. Although Beijing's strategy has been gradually developed without taking Trump's victory for granted, the existing void might be filled by its economic policies. In this regard, mainstream American media are right. Nevertheless, a step-by-step approach is required. ${ }^{17}$ RCEP could certainly be an alternative to TPP, but the stance of some Asian countries has to be examined, as they seem to be restraining factors. India is a particularly significant case. The difficult negotiating stance of New Delhi will not necessarily change as it endeavors to prevent some loss of its domestic industry by the reduction of tariffs. ${ }^{18}$ Moreover, Japan has traditionally viewed China's initiatives in a suspicious way and is finding it currently hard to adjust to new developments after Trump's inauguration.

Beijing is aware of some contradictory positions on the road to a RCEP conclusion and is prepared to invest greatly in negotiations. It is also counting on the support of Asian nations that are enthusiastic about RCEP and can partly sideline the Indian and Japanese argumentation in future deliberations. Meanwhile, however, Beijing is closely monitoring how the 45th US President formulates his trade policy after withdrawing from the 
TPP. He said he would pursue bilateral trade deals with different countries. Japanese Prime Minister Shinzo Abe, for instance, has already expressed an interest in the proposal. ${ }^{19}$ For its part, the Chinese administration does not cultivate any illusions that Trump will accept Chinese domination over international trade. By contrast, it is preparing itself for all scenarios.

\section{Foreign Policy}

In parallel with trade policies, the future evolution of Sino-American relations will be played out in the arena of foreign policy. Attention is turned towards developments in the South China Sea. A recent study published by RAND Corporation is entitled: 'War with China: Thinking through the Unthinkable' and asserts that the danger that a mishandled crisis could trigger hostilities cannot be ignored. ${ }^{20}$ As far as the approach of the new US president is concerned, in his April 2016 foreign policy speech he clarified: 'We desire to live peacefully and in friendship with China'. At the same time, however, he warned: 'Look at what China is doing in the South China Sea. They're not supposed to be doing this'. ${ }^{21}$ On the whole, he said he would bolster the US military presence in the South China Sea.

In January 2017, Rex Tillerson - then Trump's nominee for Secretary of State - expressed the view, during his Senate confirmation hearing, that China should be barred from South China Sea islands. ${ }^{22} \mathrm{He}$ also said that the building of islands and putting military assets on those islands was 'akin to Russia's taking Crimea' from Ukraine. These comments caused anger in Beijing. An editorial of Global Times was representative of how it would be prepared to respond. Although it expressed the hope that Tillerson would 'desire a productive partnership with China', it also made clear that 'if Trump's diplomatic team shapes future Sino-US ties on the basis of its current actions, the two sides had better prepare for a military clash'.23

Within this context, a critical factor for the development of the relationship between Washington and Beijing will be how the former will see its traditional allies, namely Japan and South Korea. While in his pre-election campaign Trump criticized both for extensively relying on US support, his first weeks is office are rather marked by continuity in that regard. Ahead of his South Korea visit, Secretary of Defence James Mattis reaffirmed American commitment to defend its ally and also deploy the THAAD mis- 
sile system. ${ }^{24}$ Washington publicly says that THAAD will only target North Korea - if required - but Beijing does not seem convinced and feels threatened.

From another perspective some commentators take the rapprochement between the US and Russia under Trump into account and are already attempting to explore how Vladimir Putin's alignment with the West will affect his relationship with his Chinese counterpart Xi Jinping. A recent article in The Guardian was titled: 'Some other friends forever? China wary of Rex Tillerson wooing away Russia.' ${ }^{25}$ The main argumentation is that the theoretical collaboration between the US and Russia might jeopardize the Sino-Russian partnership. The supposed explanation is that Putin will have to make difficult choices between turning his country's foreign policy towards the West or towards China.

Even if Tillerson manages to facilitate a better political understanding between Washington and Moscow, the relationship between Beijing and Moscow will hardly be influenced. To start with, there is no Sino-Russian 'axis' against the West. The fact that China and Russia closely co-operate does not mean that they seek to repudiate the US and the EU or that they are building an anti-Western military and political alliance. Also, the economic grounds for a Sino-Russian collaboration are unquestionable. Russia needs China as a reliable client for its natural gas. The bilateral May 2013 energy deal is a characteristic example. For its part, Beijing needs Moscow for the smooth implementation of its 'Belt and Road' Initiative in several Asian countries. In other words, the win-win logic cannot be easily altered. ${ }^{26}$

\section{Who leads globalization?}

The next four years will define how the new multipolar world will be shaped and if the US and China will prefer to antagonize each other or generally collaborate in spite of their differences. Ironically, a new theme where the two countries seem to proceed holding contradictory positions is that of globalization. As long as Trump's policies jeopardize the US's leading role in this process, China will have the opportunity to possibly take over its role. While Trump insists on protectionist policies, the Chinese leadership puts emphasis on the importance of globalization.

President Xi Jinping participated for the first time in the Davos World Economic Forum and made a relevant speech. ${ }^{27}$ In addition, Premier Li 
Keqiang published an article on Bloomberg, suggesting inter alia: 'Economic globalization has enabled the creation and sharing of wealth on an unprecedented scale [and China] offers an anchor of stability and growth with its consistent message of support for reform, openness, and free trade. ${ }^{28}$ A few years ago such comments would only have come from US leaders. But times have changed and they become more interesting and certainly more unpredictable.

*George N. Tzogopoulos, CIFE Alumnus, is a journalist and media-politics expert. He is founder of chinaandgreece.com and the author of the books US Foreign Policy in the European Media (IB Tauris 2012) and The Greek Crisis in the Media (ashgate 2013).

\section{References:}

1. Ian Bremmer, 'Donald Trump's Taiwan Call Is a Bad Omen for His Foreign Policy', available at: http://time.com/4594244 /donald-trumpforeign-policy- taiwan-china/, 7 December 2016 [accessed February 2017].

2. Global Times, Trump-Tsai phone call and the One-China policy, http:/ /www.globaltimes.cn/content/1021730.shtml, 3 December 2016 [accessed February 2017].

3. Wilbur Ross and Peter Navarro, 'We need a tough negotiator like Trump to fix US trade policy', http://www.cnbc.com/2016/07/29/weneed-a-tough- negotiator-like-trump-to-fix-us-trade-policy- commenta ry.html, 29 July 2016 [accessed February 2017].

4. Josh Kosman, 'Trump's possible Commerce head knows how to deal with China', http://nypost.com/2016/11/19/possible-commerce- head -ross-knows-how-to-deal-with-china/, 19 November 2016 [accessed February 2017].

5. Matthew Goldstein, 'Vulture' or 'Phoenix'? Wilbur Ross, risk-taker, is eyed for commerce post', https://www.nytimes.com/2016/11/25/busin ess/ dealbook/wilbur-ross-commerce-secretary-donald- trump.html?_r $=0,25$ November 2016 [accessed February 2017].

6. The personal website of Peter Navarro (http://www.peternavarro.com) offers information about his publication record.

7. Fortune, 'America would lose a trade war with China', available at: http://fortune.com/2016/12/22/donald- trump-china-trade-war/ 21 December 2016 [accessed February 2017]. 
8. Charles Riley, 'Why a 8 reasons why starting a trade war with China is a bad idea', available at: http://money.cnn.com/2016/11/16/news/ec onomy/us-china-trade-war-donald-trump/, 17 November 2016 [accessed February 2017].

9. Eduardo Porter, 'A Trade war against China might be a fight Trump couldn't win', available at: https://www.nytimes.com/2016/11/22/bus iness/a-trade-war-against-china-might-be-a-fight-trump- couldnt-win. html?_r=0 [accessed February 2017].

10. Global Times, 'Will Trump start a trade war against China?', available at: http://www.globaltimes.cn/ content/1017696.shtml [accessed February 2017].

11. White House website, 'Presidential Memorandum regarding withdrawal of the United States from the Trans-Pacific Partnership negotiations and agreement', available at: https://www.whitehouse.gov/the-p ress- office/2017/01/23/presidential-memorandum-regarding- withdra wal-united-states-trans-pacific [accessed February 2017].

12. Ishaan Tharoor, 'Trump kills TPP, giving China its first big win', available at: https://www.washingtonpost.com/news/worldviews/ wp/ 2017/01/24/trump-kills-tpp-giving-china-its-first-big-win/?utm_term $=.25830062427 \mathrm{~d}, 24$ January 2017 [accessed February 2017].

13. Michael Shuman, 'Trump's gift to China', available at: https:// www.bloomberg.com/view/articles/2017-01-24 / trump-s-tpp-withdrawal-is-gift-to-china, 24 January 2017, available at: https:/www.blo omberg.com/view/articles/2017-01-24/trump-s-tpp-withdrawal-is-gift - to-china [accessed February 2017].

14. Charles Riley, 'Trump's decision to kill TPP leaves door open for China', available at: http://money.cnn.com/2017/01/23/news/economy/tp p-trump-china/, 24 January 2017 [accessed February 2017].

15. George Tzogopoulos, 'China wins chance to lead APEC trade deal', available at: http://www.globaltimes.cn/content/1019063.shtml, 20 November 2016 [accessed February 2017].

16. Ministry of Foreign Affairs of the People's Republic of China website, 'China's Policies on Asia-Pacific Security Cooperation', available at: http://www.fmprc.gov.cn/mfa_eng/zxxx_662805/t1429771.shtml, 11 January 2017 [accessed February 2017].

17. George Tzogopoulos, 'Euphoria should not distract China's careful strategy', http://www.china.org.cn/opinion/2016-11/22/content_39756 866.htm, 22 November 2016 [available February 2017]. 
18. Nyshka Chandran, 'China-backed trade deal may not gain from TPP's loss. Blame India', available at: http://www.cnbc.com/2017/01/12/tru mps-win-puts-tpp-in-danger-but-china-backed-trade-deal-may-not-gai n-because-of-india.html, 12 January 2017 [accessed February 2017].

19. Reuters website, 'Japan PM says free trade talks with US possible', available at: http://www.reuters.com/article/us-japan-tpp-idUSKBN15 A0GZ, 26 January 2017 [accessed February 2017].

20. David C. Gompert, Astrid Cevallos, Cristina L. Garafola, 'War with China Thinking through the Unthinkable', available at: http://www.ra nd.org/pubs/research_reports/ RR1140.html, 2016 [accessed February 2017].

21. The New York Times website, 'Transcript: Donald Trump's Foreign Policy Speech', available at: https://www.nytimes.com/2016/04/28/us/ politics/transcript-trump-foreign-policy.html, 27 April 2016 [accessed February 2017].

22. David Brunnstrom and Matt Spetalnick, 'Is Trump ready for war in the South China Sea, or is his team just not being clear?, available at: http://www.reuters.com/article/us-congress-tillerson-china-idUSKBN 14V2KZ, 24 January 2017 [accessed February 2017].

23. Global Times website, 'Is Tillerson's bluster just a bluff for Senate? available at: http://www.globaltimes.cn/content/1028568.shtml, 13 January 2017 [accessed February 2017].

24. Emiko Jozuka and Sol Han, 'Mattis reaffirms commitment to THAAD ahead of South Korea visit', available at: http://edition.cnn.com/2017/ 01/30/asia/mattis-asia-trip-thaad/, 31 January 2017 [accessed January 2017].

25. Tom Philipps, ''Friends forever'? China wary of Rex Tillerson wooing away Russia', available at: https://www.theguardian.com/us-news/201 6/dec/14 /best-friends-forever-china-wary-of-rex-tiller-son-wooing-aw ay-russia, 14 December 2016 [accessed February 2017].

26. George Tzogopoulos, 'Tillerson, Russia and China', available at: http: //www.china.org.cn/opinion/2016-12/24/content_39972817.htm, 24 December 2016 [accessed February 2017].

27. WEC website, 'President Xi's speech to Davos in full', available at: https://www.weforum.org/agenda/2017/01/full-text-of-xi-jinping-keyn ote-at-the-world-economic-forum, 17 January 2017 [accessed February 201].

28. Li Keqiang, 'China Premier Li Keqiang: 'Economic Openness Serves Everyone Better', available at: https://www.bloomberg.com/news/arti 
cles/2017-01-26/china-premier-li-keqiang-economic-openness-serveseveryone-better,26January 2017 [accessed February 2017]. 